\title{
Regulation of Somatodendritic Dopamine Release in the Ventral Tegmental Area by Opioids and GABA: An in vivo Microdialysis Study
}

\author{
Mark A. Klitenick, ${ }^{1}$ Philippe DeWitte, ${ }^{2}$ and Peter W. Kalivas ${ }^{1}$ \\ 'Department of Veterinary and Comparative Anatomy, Pharmacology, and Physiology and Alcohol and Drug Abuse \\ Program, Washington State University, Pullman, Washington 99164-6520 and 2Laboratoire de Psychobiologie, Université \\ Catholique de Louvain, B-1348 Louvain-La-Neuve, Belgium
}

\begin{abstract}
Microdialysis of the ventral tegmental area in conscious rats was used to evaluate the influence of opioids and GABA agonists on extracellular levels of GABA and somatodendritically released dopamine. The administration of morphine through the dialysis probe elicited significant, dose-dependent increases in the levels of extracellular dopamine and significantly reduced the extracellular concentration of GABA. In contrast, a dose-dependent decrease in somatodendritic extracellular dopamine was produced following the administration of the GABA ${ }_{B}$ agonist baclofen. The increase in dopamine levels elicited by morphine $(100 \mu \mathrm{M})$ was completely blocked by either baclofen $(100 \mu \mathrm{M})$ coadministration or peripheral injection of naloxone ( $2 \mathrm{mg} / \mathrm{kg}$, i.p.). Application of the $\mathrm{GABA}_{\mathrm{A}}$ agonist muscimol produced a significant increase in both extracellular levels of dopamine and locomotor activity. The present results, together with other electrophysiological, neurochemical, and behavioral data, support a hypothesis that stimulation of $\mu$-opioid or GABA receptors inhibits the activity of GABAergic afferents to dopamine neurons, thereby removing tonic inhibitory regulation, whereas stimulation of $\mathrm{GABA}_{\mathrm{B}}$ receptors directly inhibits dopamine neurons.
\end{abstract}

The motor-stimulant effects of morphine and enkephalin analogs have been amply demonstrated following either peripheral (Judson and Goldstein, 1978; Veith et al., 1978; Kalivas and Duffy, 1987) or central (Joyce and Iversen, 1979; Kalivas et al., 1983; Vezina et al., 1987; Calenco-Choukroun et al., 1991; Shippenberg, in press) administration in rodents. A variety of evidence suggests that opioid-induced hyperactivity may be mediated, at least partially, by an increase in dopaminergic activity. For example, injection of morphine or enkephalin analogs onto the A10 dopamine cell bodies in the ventral tegmental area (VTA) elicits an increase in spontaneous locomotor activity (Broekkamp et al., 1979; Joyce and Iversen, 1979; Kelley et al., 1980; Kalivas et al., 1983; Kalivas and Duffy, 1990; Calenco-Chou-

\footnotetext{
Received Dec. 4, 1991; revised Jan. 31, 1992; accepted Feb. 10, 1992.

We thank Jenny Baylon for assistance in preparing the manuscript, Patricia Duffy for her technical expertise, and Yonas Habte. The research was supported in part by USPIIS Grants DA-03906 and MH-40817, Research Career Development Award DA-00158 (P.W.K.), National Research Service Award DA-05391 (M.A.K.), and FNRS-90-93 and FMRE-89-92 (P.D.)

Correspondence should be addressed to Mark A. Klitenick, Ph.D., Department of VCAPP, Washington State University, Pullman, WA 99164-6520.
}

Copyright (C) 1992 Society for Neuroscience $0270-6474 / 92 / 122623-10 \$ 05.00 / 0$ kroun et al., 1991) and dopamine release and metabolism in a number of mesocorticolimbic dopamine terminal fields (Kalivas et al., 1983; Latimer et al., 1987; Cador et al., 1989; Kalivas and Duffy, 1990), similar to the increase in metabolism seen following peripheral morphine (Moleman and Bruinvels, 1976; Westerink and Korf, 1976; Wood et al., 1980; Kalivas and Duffy, 1987). Also, opioid-induced locomotor activity can be blocked by dopamine antagonists (Kelly et al., 1980; Iwamoto, 1981; Kalivas et al., 1983). In addition to stimulating dopaminedependent locomotion in the VTA, rats will self administer morphine directly into the VTA (Bozarth and Wise, 1981a), and the microinjection of enkephalin into the VTA will produce conditioned place preference (Phillips et al., 1983). The fact that these behaviors require an intact dopamine system suggests that at least some of the rewarding effects of opioids in the VTA result from stimulation of the ascending mesocorticolimbic dopamine system (Bozarth and Wise, 1981b; Phillips et al., 1983; Fibiger and Phillips, 1986).

Electrophysiological studies indicate that opioids activate dopamine neurons indirectly (Gysling and Wang, 1983; Matthews and German, 1984; Lacey et al., 1989), possibly via inhibition of a tonic GABAergic input (Kelley et al., 1980; Kalivas et al., 1990; Johnson and North, 1992a). In addition to $\mu$-opioid modulation of the GABAergic input, it has been suggested that inhibition of GABA release by the activation of $G_{A B A}$ receptors results in the stimulation of dopamine neurons, again via disinhibition (Grace and Bunney, 1979; Waszczak and Walters, 1980; Kalivas et al., 1990). Whereas $\mathrm{GABA}_{\mathrm{A}}$ receptor agonists usually stimulate dopamine neurons in vivo, $\mathrm{GABA}_{\mathrm{B}}$ receptor agonists have been reported to produce inhibition (Olpe et al., 1977; Grace and Bunney, 1979, 1980; Waszczak and Walters, 1980). In contrast, in vitro electrophysiological expcriments rcveal that the stimulation of either $\mathrm{GABA}_{\mathrm{A}}$ and $\mathrm{GABA}_{\mathrm{B}}$ receptors hyperpolarizes dopamine cells (Pinnock, 1984; Lacey et al., 1988; Seabrook et al., 1990; Sugita et al., 1992).

The present study used in vivo microdialysis in the VTA of conscious rats to evaluate further the effects of opioids and GABA on somatodendritic dopamine release and extracellular levels of GABA. Previous studies have demonstrated that the extracellular levels of dopamine measured by microdialysis in the VTA and substantia nigra are calcium dependent and partially reduced by blocking voltage-dependent sodium channels and stimulating D2 autoreceptors (Kalivas and Duffy, 1991; Robertson et al., 1991; Santiago and Westerink, 1991), lending support to the utility of this approach. Alterations in the extra- 
cellular levels of dopamine and $\mathrm{G} \Lambda \mathrm{B} \Lambda$ in response to local stimulation of opioid and GABA receptors were measured to examine further a model detailing the synaptic organization of afferents to dopamine neurons in the VTA.

\section{Materials and Methods}

Animals and surgery. Adult male Sprague--Dawley rats weighing 280320 gm (Laboratory Animal Research Facility, Pullman, WA) were individually housed in wire mesh cages and kept in a temperature- and light-controlled (12 hr light/12 hr dark cycle) environment with food and water available ad libitum. Surgery was performed under Equithesin anesthesia using standard stereotaxic techniques. Bilateral guide cannula (14 mm, 20 gauge stainless steel; Small Parts, Miami, FL) were implanted $3 \mathrm{~mm}$ above the VTA (A/P, $2.6 \mathrm{~mm}$; M/L, $0.6 \mathrm{~mm}$ D/V, $-2.5 \mathrm{~mm}$; relative to the interaural line; Pellegrino et al., 1979). The guide cannulae were angled at $6^{\circ}$ in order to avoid penetration of the midsaggital sinus or cerebral aqueduct and secured to the skull with three stainless steel screws and cranioplastic cement. The guide cannulae were kept patent with 25 gauge stainless steel obturators (Small Parts). Dialysis experiments began following a mininum $7 \mathrm{~d}$ postoperative recovery period during which rats were handled for approximately 5 $\min / \mathrm{d}$.

Intracranial dialysis. The dialysis probes were constructed as described by Robinson and Whishaw (1988). Dialysis tubing extended 2.5 $\mathrm{mm}$ beyond the tip of the probe. The probe was inserted into a connector that allowed control of the depth of penetration and fixation onto the chronically implanted guide cannula (for details, see Kalivas and Duffy, 1990). The connector was attached to a liquid swivel that was located on a balance beam to minimize discomfort to the rat. The night before an experiment, a dialysis probe was inserted into the guide cannula and secured. A second dialysis experiment was performed in each rat on the contralateral side following a minimum $3 \mathrm{~d}$ intertrial interval. Dialysis buffer $\left(5 \mathrm{mM} \mathrm{KCl}, 120 \mathrm{mM} \mathrm{NaCl}, 1.8 \mathrm{mM} \mathrm{CaCl}_{2}, 1.2 \mathrm{~mm} \mathrm{MgCl}_{2}\right.$, plus $0.2 \mathrm{~mm}$ phosphate-buffered saline to give $\mathrm{pH} 7.4$ and final $\mathrm{Na}^{+}$concentration of $120.7 \mathrm{~mm}$ ) flowed through the probe $(2.13 \mu \mathrm{l} / \mathrm{min})$ for $2-$ $4 \mathrm{hr}$ prior to the collection of the first sample. Following the collection of three or four $20 \mathrm{~min}$ baseline samples, the syringe containing buffer was switched with one containing buffer plus the test drug. Syringes containing ascending concentrations of the test drug were switched at $80 \mathrm{~min}$ intervals, and samples of dialysate were collected during this time at $20 \mathrm{~min}$ intervals. In those experiments where either a single concentration of drug or a mixture of two drugs was used, the test drug(s) was applied or "pulsed" through the probe (following the collection of three or four predrug baseline dialysate samples) for a period of 20 or $80 \mathrm{~min}$. The syringe containing buffer plus drug(s) was then switched with a syringe containing dialysis buffer alone. Samples were then collected every $20 \mathrm{~min}$ for $120-180 \mathrm{~min}$. The drugs that were tested included morphine (1-1000 $\mu \mathrm{M}$; Sigma Chemical, St. Louis, MO), baclofen (1-1000 $\mu \mathrm{M}$; Sigma), and muscimol (1-1000 $\mu \mathrm{M}$; Sigma). Naloxone $\mathrm{HCl}$ (2.0 mg/kg, i.p.; Endo Laboratories, Garden City, NY) was dissolved in saline.

Determination of dopamine and morphine. Dialysis samples were collected into $20 \mu \mathrm{l}$ of mobile phase $\left(0.1 \mathrm{M}\right.$ citric acid, $75 \mathrm{mM} \mathrm{Na}_{2} \mathrm{HPO}_{4}$, 0.6-1.0 mM heptane sulfonic acid, 0.1 mM EDTA, $13 \%$ methanol, $\mathrm{v} / \mathrm{v}$, $\mathrm{pH} 3.8-4.2$ ) containing $2.0 \mathrm{pmol}$ of dihydroxybenzylamine as the internal standard. The concentration of dopamine within the sample was determined using HPLC-EC. Separation of biogenic amines was achieved with a reversed-phase column $(\mathrm{C}-18,25 \mathrm{~cm}$; Bioanalytical Systems, Indianapolis, IN), and detection was performed with a coulometric electrochemical system (ESA, Inc., Bedford, MA) consisting of three electrodes (guard electrode, $+0.4 \mathrm{~V}$; preoxidation electrode, $+0.35 \mathrm{~V}$; working electrode, $-0.20 \mathrm{~V}$ ). The entire sample was injected, and standard curves ranging from 0.01 to $10 \mathrm{pmol}$ were used to quantify dopamine concentration.

In vitro morphine transport into the dialysis probe was measured by placing a dialysis probe in ascending concentrations of morphine sulfate, dissolved into dialysis buffer, using a flow rate of $2.13 \mu \mathrm{l} / \mathrm{min}$ and at room temperature. Morphine concentration was determined using the same HPLC-EC system used to detect dopamine except that the preoxidation electrode was set at $+0.02 \mathrm{~V}$ and the working electrode was set at $+0.35 \mathrm{~V}$.

Determination of extracellular GABA. Samples for the GABA assay were collected into $10 \mu \mathrm{l}$ of $5.0 \mu \mathrm{M} 5$-aminovaleric acid (AVA) in 0.1 $\mathrm{M} \mathrm{HCl}$. The concentration of GABA was determined using HPLC-EC following precolumn 0 -phthalaldehyde derivatization (Bourdelais and Kalivas, 1991). Separation of GABA was achieved with a reversedphase column $(100 \times 3.2 \mathrm{~mm}$ Biophase-II, ODS $3 \mu \mathrm{M}$; BAS $)$ and detected coulometrically (ESA, Inc.) using three electrodes: a guard $(+0.7$ $\mathrm{V})$, preoxidation $(+0.2 \mathrm{~V})$, and working $(+0.4 \mathrm{~V})$ electrode. Mobile phase consisted of $0.2 \mathrm{~m}$ sodium acetate and $42 \%$ acetonitrile $(\mathrm{v} / \mathrm{v}), \mathrm{pH}$ 4.57. Standard curves ranging from $10^{-13}$ to $10^{-11} \mathrm{~mol}$ of $\mathrm{GABA}$ and AVA were used to quantify the concentration of GABA.

Histology and statistics. Upon completion of dialysis experiments, rats were killed by an overdose of sodium pentobarbital and phosphatebuffered saline was perfused transcardially followed by $10 \%$ formalin. The brain was removed and stored in formalin for at least 1 week. Coronal sections through the extent of the cannula tracks were cut (100 $\mu \mathrm{m}$ ) with a vibratome and then mounted on gelatin-coated slides and stained with cresyl violet. The location of the dialysis probe tracks was determined by an observer unaware of the animal's neurochemical response. In some rats, immunocytochemistry for tyrosine hydroxylase was performed as described elsewhere (Kalivas and Duffy, 1991).

Neurochemical and behavioral (behavioral data were only available following the administration of muscimol) dose-response data were transformed into data points that represented the average of the last two $20 \mathrm{~min}$ dialysis (or behavioral) samples for each dose, and then analyzed by a one-way analysis of variance (ANOVA) followed by Dunnett's multiple comparisons. Other neurochemical data were analyzed by a two-way, repeated-measures analysis of variance followed by the least-significant difference test for multiple comparisons (Milliken and Johnson, 1984). The neurochemical data were converted to the percentage change from the average of three baseline measurements and are represented as such in the figures. Basal dopamine levels in the VTA (mean \pm SEM), not corrected for probe recovery, were calculated from the three predrug baseline values and are expressed as $\mathrm{fmol} / 20 \mathrm{~min}$.

\section{Results}

\section{Morphine regulation of extracellular dopamine}

A dose-response curve for the effect of morphine on extracellular dopamine content in the VTA is illustrated in Figure $1 A$. The administration of the higher concentrations of morphine (100 and $1000 \mu \mathrm{M}$ ) through the dialysis probe elicited a significant increase in the extracellular levels of dopamine in the VTA (Fig. $1 B$ ). The levels were increased by approximately $250 \%$ following $100 \mu \mathrm{M}$, and $600 \%$ in response to $1000 \mu \mathrm{M}$ morphine.

Figure 2 shows the effect of morphine, naloxone, and a combination of both on extracellular dopamine in the VTA. Following a $20 \mathrm{~min}$ pulse of morphine $(100 \mu \mathrm{M})$, the levels of dopamine gradually increased. The maximal cffect was an approximate $175 \%$ increase above baseline values that occurred 40-60 min after the pulse and gradually returned to baseline levels $120 \mathrm{~min}$ after the pulse. The morphine-induced increase in dopamine was significantly attenuated by pretreatment with naloxone $(2.0 \mathrm{mg} / \mathrm{kg}$, i.p.), which by itself did not alter the extracellular concentration of dopamine.

\section{Morphine regulation of extracellular $G A B A$}

The effect of morphine administration on the concentration of extracellular GABA in the VTA is shown in Figure 3. Application of morphine $(100 \mu \mathrm{M})$ into the VTA through the dialysis probe produced a maximum $68 \%$ reduction in GABA levels during the $80 \mathrm{~min}$ administration period. The levels of GABA gradually returned to predrug values following the removal of morphine from the dialysis buffer. In contrast, levels of extracellular GABA were not significantly altered following the syringe switch containing only dialysis buffer.

\section{Regulation of extracellular dopamine by baclofen}

Figure $4 A$ shows a dose-response curve for the effect of baclofen on extracellular dopamine levels in the VTA. In contrast to the effects of morphine, baclofen decreased the extracellular do- 

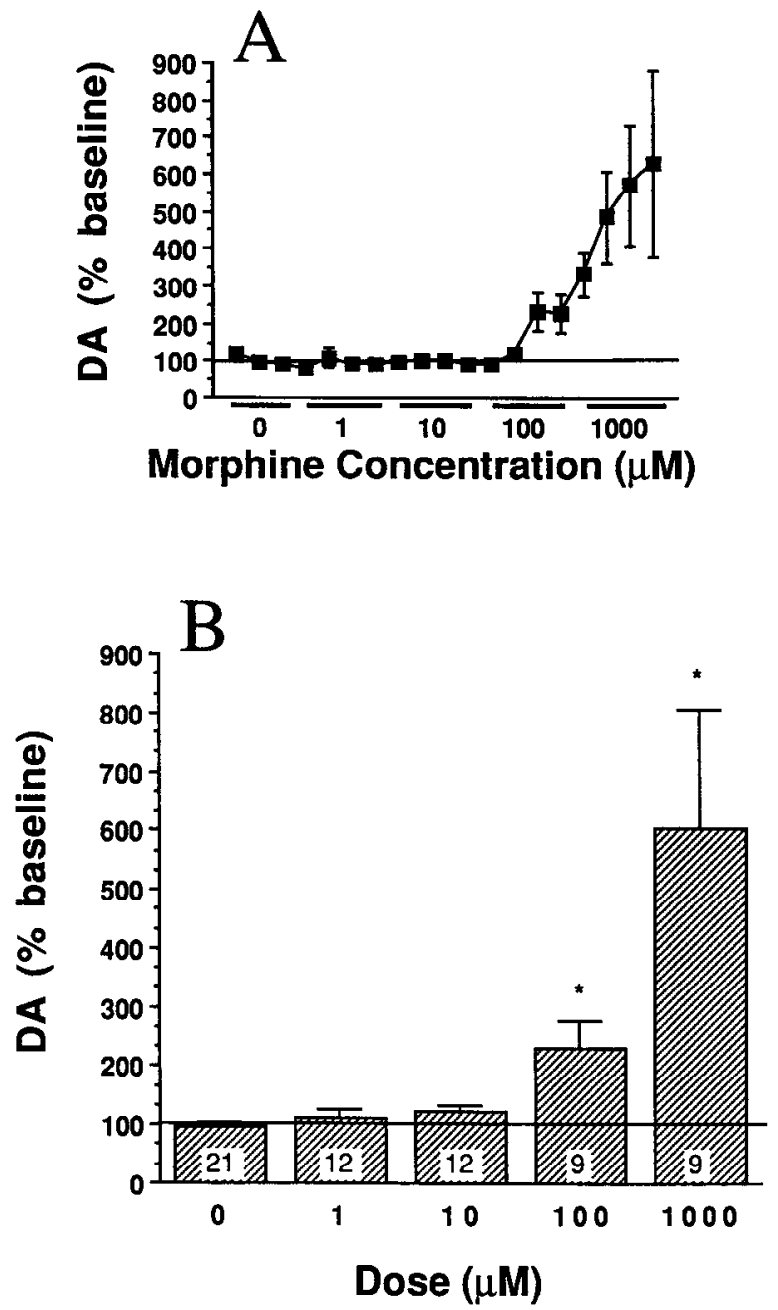

Figure 1. A, The effects of morphine (1-1000 $\mu \mathrm{M})$ administration through the dialysis probe on extracellular levels of dopamine in the VTA. B, The transformed data (see Materials and Methods) were analyzed with a one-way ANOVA followed by Dunnett's multiple comparisons. The $F$ score for dose was $F(4,32)=5.37, p=0.002{ }^{*}, p<$ 0.05 , using a Dunnett's test for comparison to predrug baseline. The number of subjects for each dose is indicated in the bar graph $(B)$. Basal dopamine levels in the VTA were $64 \pm 8 \mathrm{fmol} / 20 \mathrm{~min}$.

pamine content in the VTA. Following the two highest doses of baclofen ( 100 and $1000 \mu \mathrm{M}$ ), dopamine concentrations in the VTA were reduced to approximately $40 \%$ and $25 \%$ of baseline levels, respectively (Fig. $4 B$ ).

Figure 5 shows the effect of a 20 min pulse of either morphine $(100 \mu \mathrm{M})$, baclofen $(100 \mu \mathrm{M})$, or an equimolar mixture on extracellular dopamine levels in the VTA. The morphine pulse elicited a significant increase in dopamine release, approximately $175 \%$ above baseline levels. Following a $20 \mathrm{~min}$ pulse of baclofen, the levels of dopamine dropped to $50 \%$ of baseline values for the remainder of the experiment (120 min). A similar reduction in the level of extracellular dopamine was produced following a $20 \mathrm{~min}$ pulse of an equimolar mixture of morphine and baclofen, which decreased dopamine levels to approximately $60 \%$ of the predrug baseline.

\section{Effect of muscimol on extracellular dopamine}

A dose-response curve of the effect of muscimol on dopamine levels in the VTA is shown in Figure $6 \mathrm{~A}$. Application of mus-

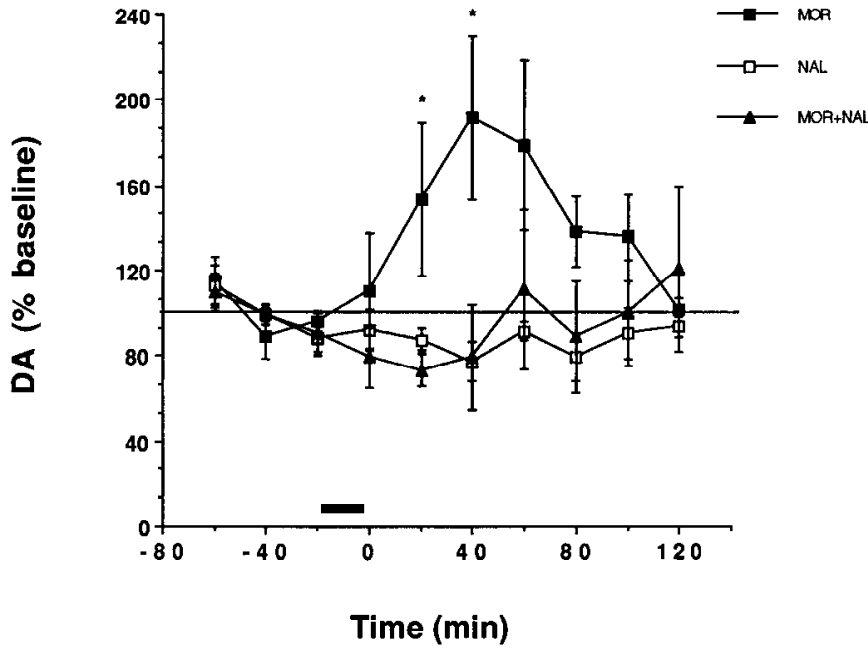

Figure 2. Levels of dopamine in the VTA following application of morphine, $100 \mu \mathrm{M}(\square)$; naloxone, $2 \mathrm{mg} / \mathrm{kg}$, i.p. ( $\square$ ); or a combination (А). $N=6-8$ per group. Thick bar indicates duration of morphine infusion. The $F$ scores were treatment $F(2,17)=7.43, p=0.01$; time $F(7,119)=1.23, p>0.5$; and interaction $F(14,119)=2.97, p=0.002$. $*, p<0.05$ compared to morphine + naloxone using a least significant difference test for multiple comparisons (Milliken and Johnson, 1984). Basal dopamine levels were $M O R, 41 \pm 11 \mathrm{fmol} / 20 \mathrm{~min} ; N A L, 43 \pm$ $10 \mathrm{fmol} / 20 \mathrm{~min} ; M O R+N A L, 40 \pm 13 \mathrm{fmol} / 20 \mathrm{~min}$.

cimol through the dialysis probe into the VTA elicited a significant increase in the extracellular levels of dopamine. An approximate $200 \%$ increase in dopamine levels was produced following the administration of 10 and $100 \mu \mathrm{M}$ muscimol (Fig. $6 B$ ), but when the concentration was increased to $1000 \mu \mathrm{M}$, the levels of extracellular dopamine returned to baseline values. A pronounced increase in motor activity, in the form of contralateral rotation, was elicited following the three highest doses

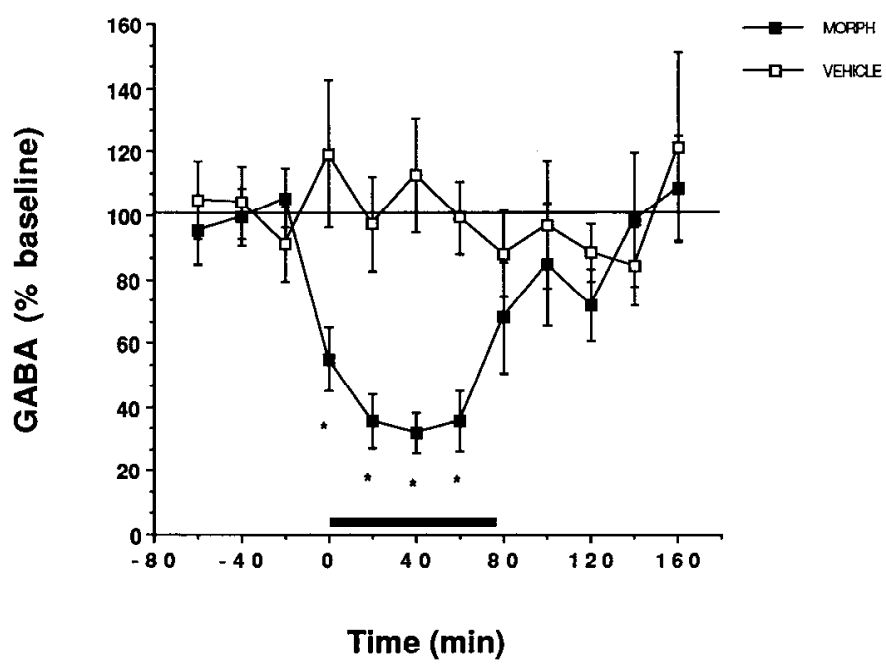

Figure 3. The effects of morphine administration into the VTA through the dialysis probe on extracellular levels of GABA. Either morphine, $100 \mu \mathrm{M}(\boldsymbol{\square}, N=14)$, or dialysis buffer alone $(\square, N=8)$ was "pulsed" into the VTA for $80 \mathrm{~min}$, and then switched to buffer for an additional $80 \mathrm{~min}$. The $F$ score for drug treatment was $F(1,20)=8.89, p=0.007$; time $F(11,220)=3.459, p=0.002$; and the drug $\times$ time interaction $F(11,220)=2.521, p=0.005 .^{*}, p<0.05$ compared to dialysis buffer alone. Basal levels of GABA in the VTA were $163.4 \pm 19.6 \mathrm{fmol} / 20$ min for morphine (ID), and $172.9 \pm 15.1 \mathrm{fmol} / 20 \mathrm{~min}$ for dialysis buffer (). Thick bar indicates duration of drug administration. 

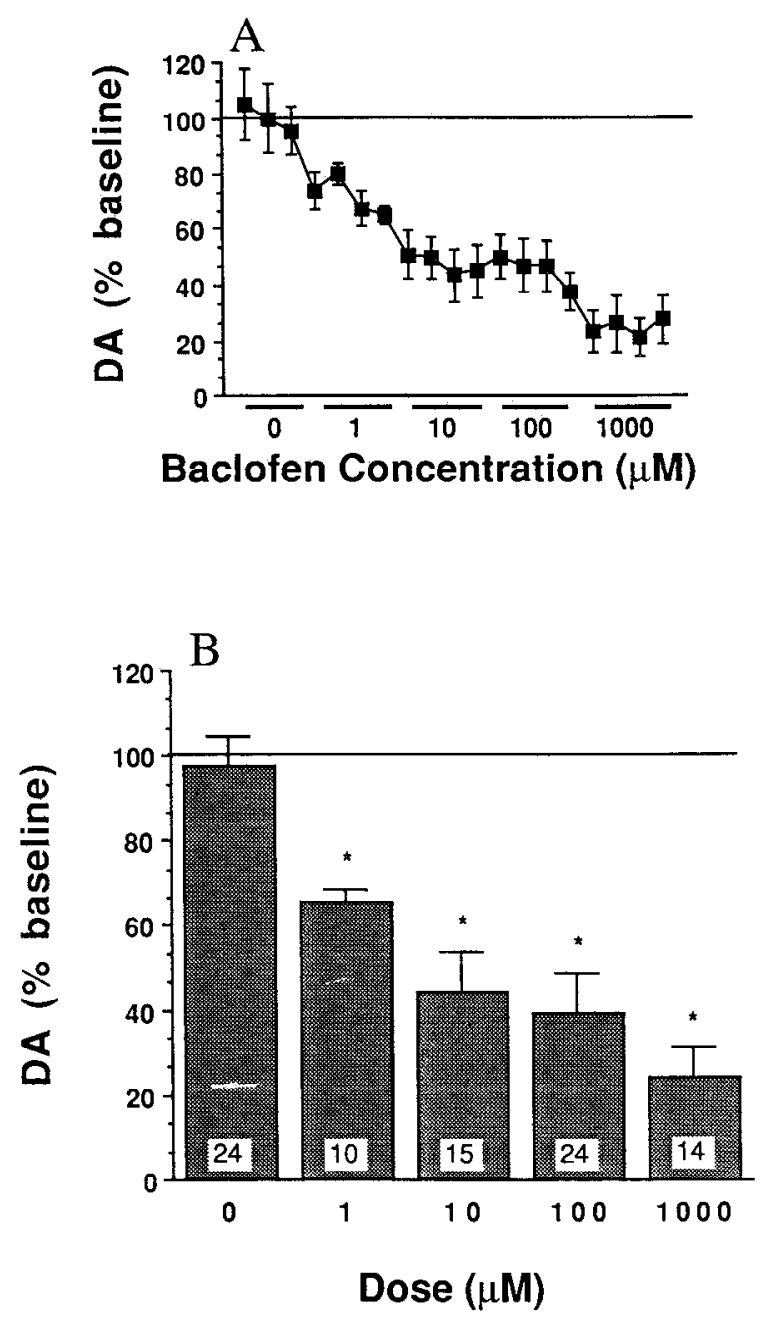

Figure 4. A, Dose-response curve for the effects of baclofen administration on extracellular dopamine levels in the VTA. Baclofen (1-1000 $\mu \mathrm{M})$ was applied in ascending concentrations through the dialysis probe. $B$, The transformed data (see Materials and Methods) were analyzed with a one-way ANOVA followed by Dunnett's multiple comparisons. $N=10-24$ for each dose as indicated on the bar graph $(B)$. The $F$ score for dose was $F(4,24)=14.68, p=0.0001 .^{*}, p<0.05$ compared to predrug baseline. Basal levels of dopamine were $71 \pm 15 \mathrm{fmol} / 20 \mathrm{~min}$.

$(10,100$, and $1000 \mu \mathrm{M})$ of muscimol tested (Fig. 6C). The maximal effect on motor activity was seen at the $100 \mu \mathrm{M}$ dose (Fig. $6 D$ ) and was characterized by tight, head-to-tail circling. Following the higher doses of muscimol, an apparent dissociation of the neurochemistry from the behavioral response is evident as motor activity remained elevated even as extracellular levels of dopamine declined. The uniphasic behavioral response may be attributable to a nonspecific action produced by muscimol at the higher doses.

\section{Control treatments and histology}

Figure 7 shows the effects of (1) switching the syringe and (2) peripheral administration of saline on the extracellular levels of dopamine in the VTA. Following the collection of three $20 \mathrm{~min}$ baseline samples of dialysate, the syringe containing buffer was switched with one also containing buffer and samples were collected for an additional $140 \mathrm{~min}$. The same animals then received an injection of saline $(1.0 \mathrm{ml} / \mathrm{kg}$, i.p.), and samples of dialysate were collected for $140 \mathrm{~min}$. There were no significant

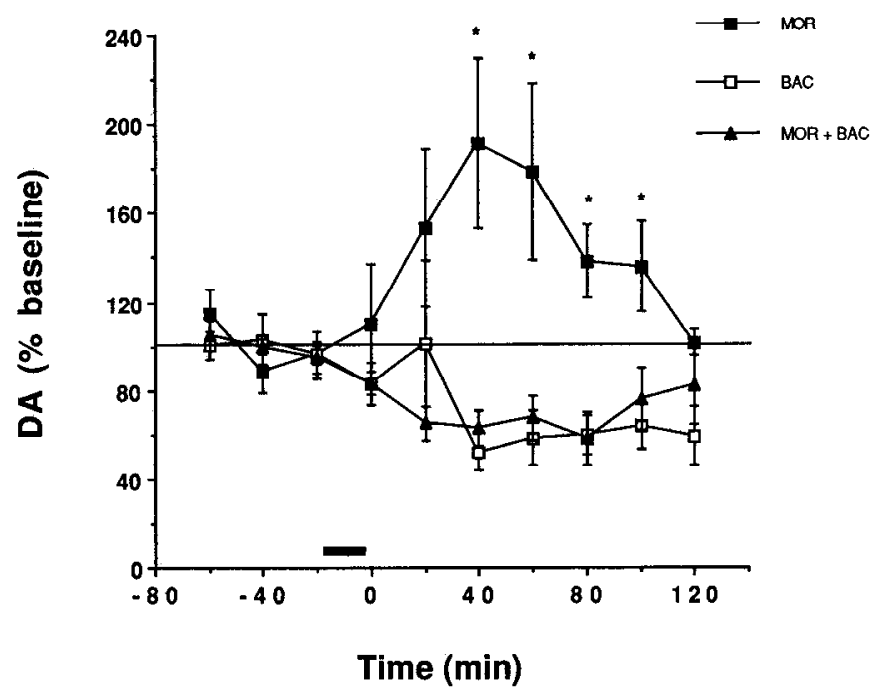

Figure 5. The effects of morphine, $100 \mu \mathrm{M}(\square)$; baclofen, $100 \mu \mathrm{M}(\square)$; or an equimolar mixture $(\Delta)$ on extracellular levels of dopamine in the VTA. $N=8-10$ per group. The morphine alone data are the same as those shown in Figure 2. Drug administration is indicated by the thick bar. The $F$ scores for treatment were $F(2,22)=14.46, p=0.0001$; time $F(7,14)=0.701, p>0.5$; and interaction $F(14,154)=2.672, p=0.001$. $*, p<0.05$ compared to morphine + baclofen using a least significant difference test (Milliken and Johnson, 1984). Basal levels of dopamine in the VT $\Lambda$ were $M O R, 41 \pm 11 \mathrm{fmol} / 20 \mathrm{~min} ; B A C, 38 \pm 5 \mathrm{fmol} / 20$ $\mathrm{min}$; and $M O R+B A C, 42 \pm 11 \mathrm{fmol} / 20 \mathrm{~min}$.

effects on the levels of dopamine following either the syringe switch or the systemic saline injection.

Figure 8 shows the in vitro recovery of morphine through the dialysis probe. The probe was placed in dialysis buffer containing various concentrations of morphine $(0.1-100 \mu \mathrm{M})$, and a 20 min sample was collected. The relative percentage recovery in vitro at room temperature ranged from approximately $3 \%$ at 0.1 $\mu \mathrm{M}$ to $5.6 \%$ at $100 \mu \mathrm{M}$ morphine. The low transport of morphine across the dialysis membrane may account for the relatively slow onset of the morphine-induced effects on extracellular dopamine and the necessity of using a concentration of $100 \mu \mathrm{M}$ to produce an effect (see Figs. $1 A, 2$ ).

A photomicrograph of a typical bilateral placement terminating in the nucleus paranigralis of the VTA is shown in Figure $9 A$. This section, stained with cresyl violet, is at a level showing the maximal extent of the damage produced by the cannula tracks. Neurons in the ventral mesencephalon immunohistochemically stained for tyrosine hydroxylase are shown in Figure $9 B$. The area outlined in white, adjacent to the cannula track, is shown in Figure $9 C$. Note the presence of what appear to be healthy neurons immunohistochemically stained for tyrosine hydroxylase, some with a visible nucleus, in the vicinity of the glial scar produced by the track of the dialysis probe.

\section{Discussion}

The results of the present experiments demonstrate that the administration of morphine through a dialysis probe into the VTA elicits an increase in the levels of extracellular dopamine and a reduction in levels of GABA. The morphine-induced increase in dopamine was reversed by peripheral naloxone pretreatment, arguing that morphine acts on opioid receptors to promote somatodendritic dopamine release. This conclusion is in agreement with behavioral (Broekkamp et al., 1979; Kelley 

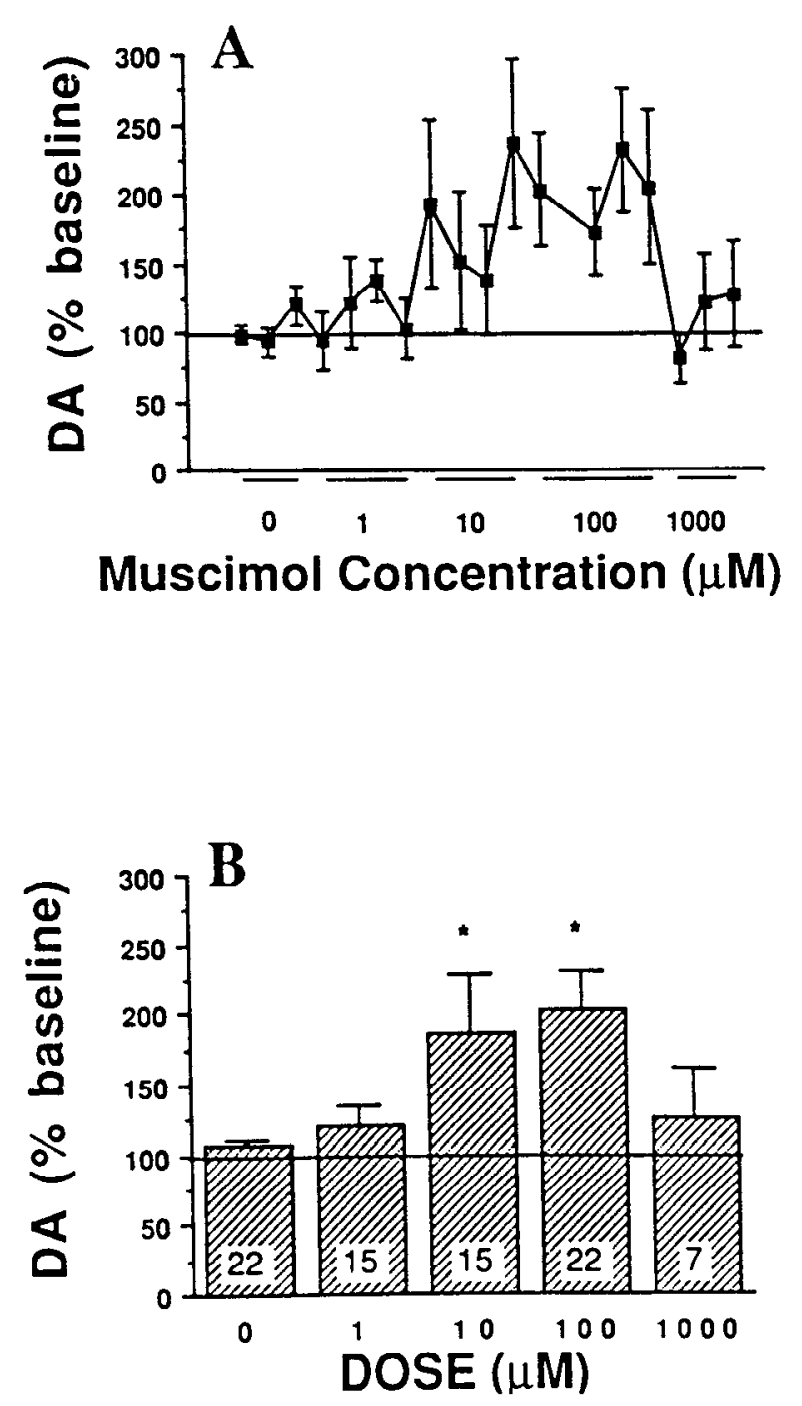
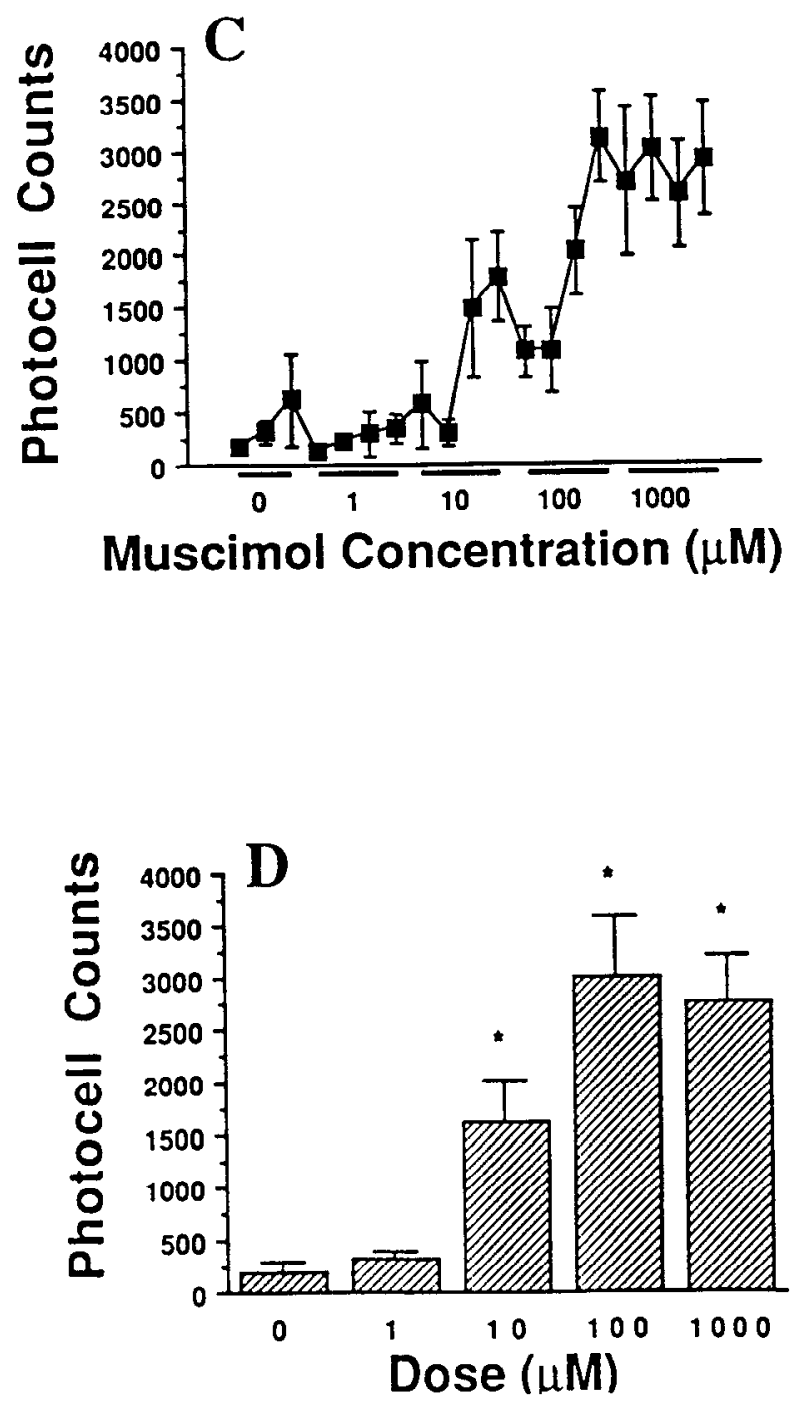

Figure 6. Effects of muscimol on extracellular dopamine and motor activity. $A$, A dose-response curve of the effects of muscimol administration on dopamine levels in the VTA. Muscimol (1-1000 $\mu \mathrm{M})$ was applied through the dialysis probe into the VTA. $B$, The data were transformed (see Materials and Methods) and analyzed with a one-way ANOVA followed by Dunnett's multiple comparisons. $N=7-22$ for each dose as indicated in the bar graph $(B)$. The $F$ score for drug dose was $F(4,24)=2.93, p=0.04 .^{*}, p<0.05$ compared to predrug baseline. The basal level of dopamine in the VTA was $68+17 \mathrm{fmol} / 20 \mathrm{~min}$. $C$, The effects of muscimol administration into the VTA on locomotor activity. $D$, The transformed data were analyzed with a one-way ANOVA followed by Dunnett's multiple comparisons. $N=8$. The $F$ score for drug dose was $F(4,28)=17.4, p=$ $0.0001 ; *, p<0.05$ compared to predrug baseline.

et al., 1980; Joyce et al., 1981; Kalivas et al., 1983; CalencoChoukroun et al., 1991) and neurochemical (Latimer et al., 1987; Cador et al., 1989; Kalivas and Duffy, 1990) evidence suggesting that dopamine neurons in the VTA are activated by $\mu$-opioids.

Although morphine stimulates dopamine neuronal activity and somatodendritic dopamine release, this effect has been proposed to occur via disinhibition. The stimulation of dopamine neurons in the VTA by iontophoretic morphine is not reversed by naloxone, while the inhibition of nondopamine cells is naloxone reversible (Gysling and Wang, 1983). Other studies have also shown that nondopamine cells are inhibited by local application of morphine (Hommer and Pert, 1983; Matthews and German, 1984). Lacey et al. (1989) used tissue slices from the rat substantia nigra to demonstrate that nondopamine neurons are hyperpolarized, while dopamine neurons are unaffected by the $\mu$-opioid agonist Tyr-D-Ala-Gly-MePhe-Gly(ol) (DAMGO). More recently, a similar observation was made in tissue slices from the rat VTA, where $\mu$-opioid agonists inhibited only nondopaminergic cells (Johnson and North, 1992a). Furthermore, this effect was produced by $\mu$ - and not by $\delta$-opioid agonists. The lack of a direct effect of morphine on dopamine cells identified in these electrophysiological studies has been corroborated using receptor autoradiography for the $\mu$-opioid ligand ${ }^{125} \mathrm{I}-\mathrm{DAMGO}$. Although destruction of dopamine neurons with 6-hydroxydopamine (6-OHDA) did not alter ${ }^{125}$ I-DAMGO binding in the VTA, quinolinic acid lesions resulted in a significant reduction (Dilts and Kalivas, 1989). Likewise, 6-OHDA lesions of the VTA did not alter the binding density of the $\delta$-opioid ligand ${ }^{125} \mathrm{I}$-[D-penicillamine ${ }^{2,5}$ ]-enkephalin (Dilts and Kalivas, 1990).

In apparent contrast to the localization of $\mu$ - and $\delta$-receptors to nondopaminergic elements within the VTA, electron micrographs of the VTA that were double labeled for enkephalin and tyrosine hydroxylase immunoreactivity revealed that many enkephalin-containing boutons abut tyrosine hydroxylase-containing perikarya (Sesack and Pickel, 1990). However, more 


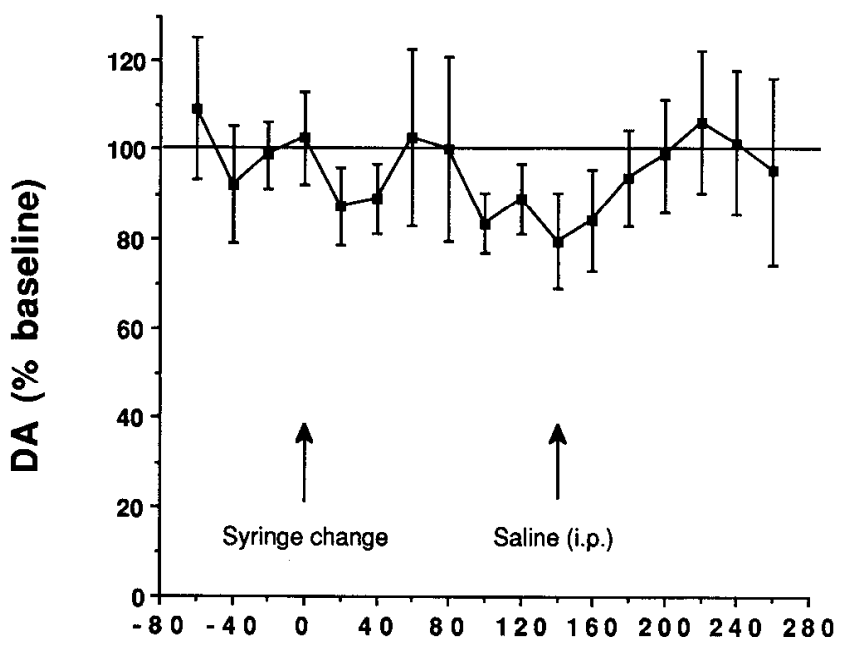

Time (min)

Figure 7. Extracellular levels of dopamine in the VTA following a change of syringes, both containing dialysis buffer alone, and after an injection of saline $(1.0 \mathrm{ml} / \mathrm{kg}$, i.p.), both indicated by arrows. The data were analyzed with a one-way repeated-measures ANOVA. $N=9$. The $F$ score for subjects was $F(8,144)=1.16, \mathrm{NS}$; time $F(16,128)=0.48$, NS. Basal dopamine levels were $38 \pm 6 \mathrm{fmol} / 20 \mathrm{~min}$.

detailed analysis of the morphology has demonstrated that densecore vesicles containing enkephalin immunoreactivity were generally not localized at points of synaptic contact on dopamine cells, suggesting a nonsynaptic release (Scsack and Pickcl, 1992). This anatomical observation, together with both electrophysiological findings demonstrating a lack of effect by opioids on dopamine cell membrane potential (Lacey et al., 1989; Johnson and North, 1992a), and autoradiographic evidence showing an apparent lack of $\mu$-or $\delta$-receptors on dopamine cells (Dilts and Kalivas, 1989, 1990), indicates that released enkephalin may have a paracrine-like function and diffuses into the extracellular space to act on nondopaminergic neurons and axon terminals adjacent to dopamine neurons in the VTA. Although the source of enkephalin terminals in the VTA is not well defined, there exist almost no enkephalin-immunoreactive neurons intrinsic to the VTA (Johnson et al., 1980; Khachaturian et al., 1983), and we recently observed that approximately $8 \%$ of the neurons in the nucleus accumbens and ventral pallidum retrogradely labeled by fluorogold iontophoresis into the VTA contained preproenkephalin mRNA (M. A. Klitenick and P. W. Kalivas, unpublished observations).

The observation that morphine significantly reduced the concentration of extracellular GABA argues that at least a portion of the opioid receptors are on GABAergic neurons and/or presynaptic terminals in the VTA. Many of the nondopaminergic neurons in the VTA are thought to be GABAergic, have been shown to contain GABA, the GABA synthetic enzyme glutamic acid decarboxylase (GAD), as well as GAD mRNA (Fonnum et al., 1978; Ribak et al., 1980; Nagai et al., 1983; Ottersen and Storm-Mathisen, 1984; Sequier et al., 1988; Zhang et al., 1991), and may innervate dopaminergic cells within the VTA (Nagai et al., 1983; Ottersen and Storm-Mathisen, 1984). Also, descending projections from the nucleus accumbens and ventral pallidum are thought to be GABAergic, and provide inhibitory feedback onto dopamine cells in response to axonal dopamine

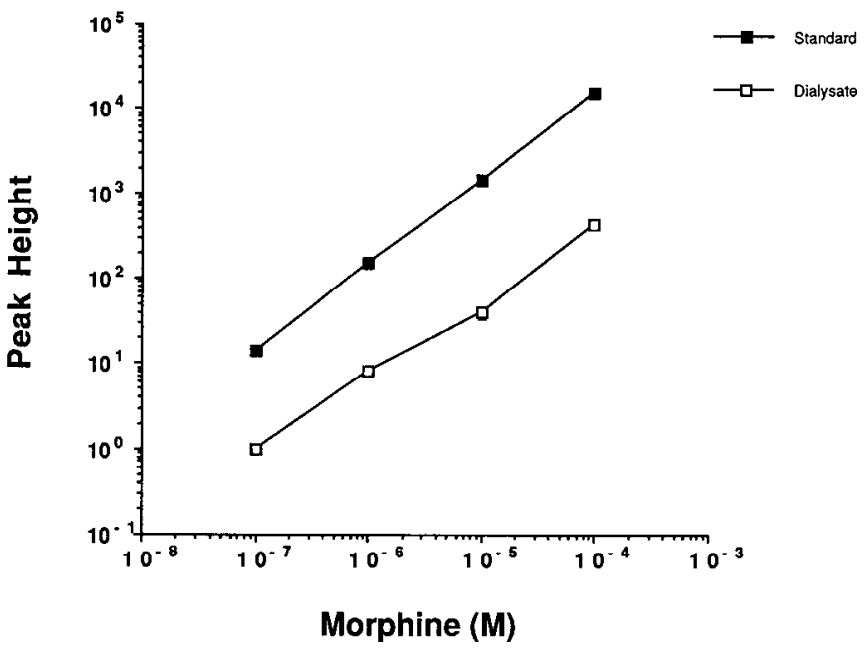

Figure 8. The in vitro recovery of various concentrations of morphine $(0.1-100 \mu \mathrm{M})$ through the dialysis probe at room temperature. Each data point represents the mean of four dialysis probes.

release (Fonnum et al., 1978; Yim and Mogenson, 1980; Grace and Bunney, 1985; Haber et al., 1985). The presence of both GABA receptor subtypes has been demonstrated within the ventral mesencephalon (Bowery et al., 1987; Churchill et al., 1992), and it is clear from intracellular recording of dopamine neurons in tissue slices that both $\mathrm{GABA}_{\mathrm{A}}$ and $\mathrm{GABA}_{\mathrm{B}}$ receptors are located on dopamine neurons (Lacey et al., 1988; Johnson and North, 1992b). While GABA $_{\mathbf{B}}$ receptor stimulation elicits a late onsct, long-duration hyperpolarization mediated by increased potassium conductance, stimulation of $\mathrm{GABA}_{\mathrm{A}}$ receptors produces a short-lived hyperpolarization mediated by increased chloride flux (Lacey et al., 1988; Seabrook et al., 1990; Johnson and North, 1992b). Recent studies by North and coworkers indicate that the synaptic inputs to the $G_{A B A}$ and $\mathrm{GABA}_{\mathrm{B}}$ receptors on dopamine neurons are anatomically distinct, and originate from local interneurons and projections into the VTA, respectively (Johnson and North, 1992b; Sugita et al., 1992). Furthermore, both the spontaneous and electrically stimulated GABA-dependent hyperpolarizations were inhibited by DAMGO (Johnson and North, 1992a). In contrast to the findings of Sugita et al. (1992) and Johnson and North (1992a), Yim and Mogenson (1980) showed that the hyperpolarizations produced by in vivo electrical stimulation of the nucleus accumbens were blocked by the indirect $\mathrm{GABA}_{\mathrm{A}}$ antagonist picrotoxin.

The hyperpolarization of dopamine cells by stimulating GA$B A_{B}$ receptors is consistent with the present observation that baclofen decreases extracellular dopamine content in the VTA. Furthermore, it is consistent with in vivo electrophysiological and behavioral studies showing that baclofen inhibits impulse generation in dopamine cells (Olpe et al., 1977; Grace and Bunney, 1980) and decreases the locomotor activity (Tanner, 1979; Kalivas et al., 1990). However, the fact that the GABA ${ }_{\mathrm{A}}$ agonist muscimol increased somatodendritic dopamine release is inconsistent with the observation that the stimulation of $\mathrm{GABA}_{\mathrm{A}}$ receptors on dopamine neurons elicits membrane hyperpolarization. This inconsistency may result from a difference in the basal activity of the GABAergic afferents to dopamine neurons in vivo, as compared to in vitro tissue slices. Earlier in vivo electrophysiological experiments revealed that systemic muscimol inhibits nondopamine cells, while simultaneously stim- 

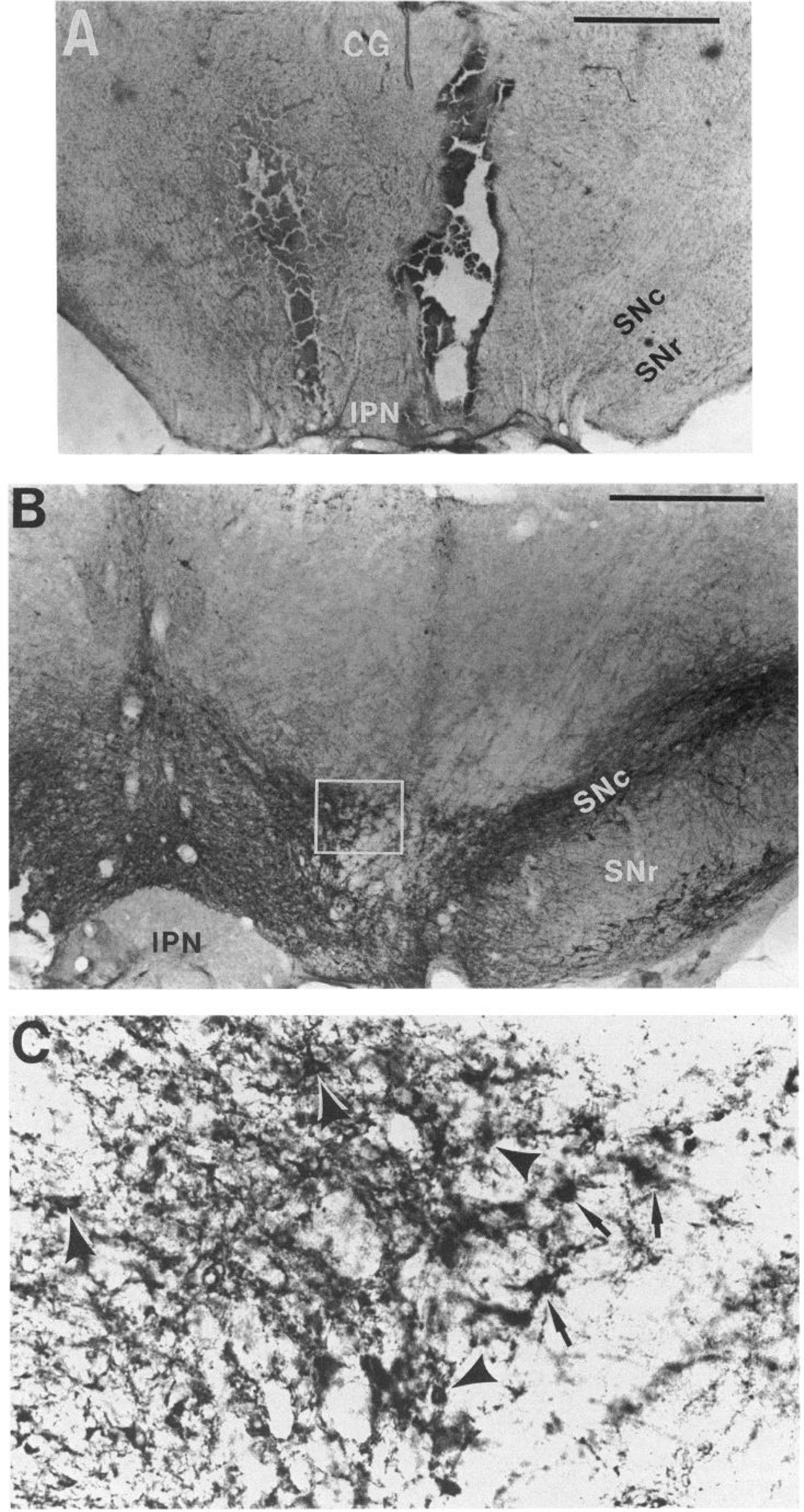

Figure 9. Photomicrographs of typical cannula/probe placements in the VTA. $A$, Cresyl violet-stained section through the middle of the cannula tracks. $B$, Neurons in the VTA and substantia nigra immunohistochemically stained for tyrosine hydroxylase. C, High-power micrograph of the area in the vicinity of the track of the probe, boxed in $B$. Neurons of normal appearance, stained for tyrosine hydroxylase (arrows), some with a visible nucleus (arrowheads), are seen adjacent to the glial scar. $C G$, central gray; $I P N$, interpeduncular nucleus; $S N C$, substantia nigra, pars compacta; $S N r$, substantia nigra, pars reticulata. Magnification: $A, 20 \times ; B, 40 \times ; C, 200 \times$. Scale bars: $A, 1 \mathrm{~mm} ; B, 0.5 \mathrm{~mm}$. 
Figure 10. An illustration representing the afferent input to dopamine neurons and the location of receptors that is consistent with the effect of GABA and opioid agonists on levels of extracellular dopamine and GABA in the VTA.

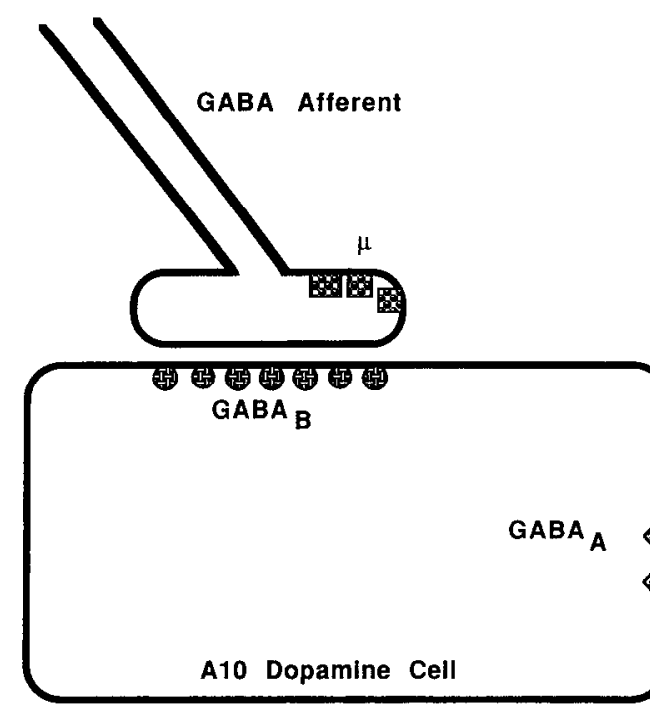

ulating dopamine neurons in the ventral mesencephalon (MacNeil et al., 1978; Walters and Lakoski, 1978; Grace and Bunney, 1979; Waszczack and Walters, 1980). Furthermore, iontophoretic GABA was found to be approximately 20 times more potent at inhibiting nondopamine cells compared to dopamine neurons (Grace and Bunney, 1979). Likewise, low levels of electrical stimulation of striatonigral GABAergic feedback preferentially inhibited the firing frequency of nondopamine versus dopamine cells (Grace and Bunney, 1985). The differential sensitivity of dopamine and nondopamine cells to $\mathrm{GABA}_{\mathrm{A}}$ agonists may explain the biphasic dose-response curve for muscimol-induced elevation in extracellular dopamine. Thus, the lower concentrations of muscimol would preferentially inhibit nondopamine cells, thereby indirectly stimulating dopamine neurons. The disinhibition of dopamine cells by $\mathrm{GABA}_{\mathrm{A}}$ agonists is further supported by the fact that the microinjection of muscimol into the VTA elicits motor stimulation that is associated with an increase in dopamine transmission in axon terminals (Wirtshafter and Klitenick, 1989; Kalivas et al., 1990). Also, muscimol induced an efflux of dopamine from the VTA in tissue slices (Beart and McDonald, 1980). Based upon these data, it is possible that the predominant in vivo tone preferentially stimulates $\mathrm{GABA}_{\mathrm{A}}$ receptors on nondopamine cells. The observation that 6-OHDA lesions did not lower the density of ${ }^{3} \mathrm{H}$-muscimol binding indicates that $\mathrm{GABA}_{\mathrm{A}}$ receptors are more densely localized on nondopaminergic elements in the VTA (Churchill et al., 1992). Furthermore, the microinjection of the indirect $\mathrm{GABA}_{\mathrm{A}}$ antagonist picrotoxin into the substantia nigra promoted the release of preloaded ${ }^{3} \mathrm{H}-\mathrm{GABA}$, indicating tonic stimulation of $\mathrm{GABA}_{\mathrm{A}}$ receptors on GABAergic neurons (Kondo and Iwatsubo, 1978). This conclusion is also supported by some studies showing that the application of muscimol in vitro inhibits the release of radiolabeled GABA from substantia nigra tissue slices (Kondo and Iwatsubo, 1978; Floran et al., 1988). However, in one study using synaptosomes prepared from the substantia nigra, no evidence was obtained for the modulation of GABA release by GABA $_{4}$ receptor stimulation (Giralt et al., 1990).

Figure 10 shows a model that illustrates how opioids and GABA may modulate dopamine cells in the VTA. (It should be noted, however, that glial cells, which may also be involved in the regulation of transmitter levels in the VTA, have not been included in the present model.) The dopamine cell is innervated by GABA-containing terminals from two sources, a GABAergic interneuron and a descending input from the nucleus accumbens or ventral pallidum (Waalas and Fonnum, 1980; Ottersen and Storm-Mathisen, 1984). The innervation from the descending input is to $\mathrm{GABA}_{\mathrm{B}}$ receptors, while the interneuron stimulates $\mathrm{GABA}_{\mathrm{A}}$ receptors (Johnson and North, 1992b; Sugita et al., 1992). In addition, $\mathrm{GABA}_{\mathrm{A}}$ receptors on the $\mathrm{GABA}$ interneuron are innervated by descending GABAergic projections from the nucleus accumbens or ventral pallidum (Grace and Bunney, 1985; Johnson and North, 1992b; Churchill et al., 1992). $\mu$-Opioid receptors are located presynaptically on descending GABAergic axon terminals innervating dopamine cells, as well as on the GABAergic interneuron (Dilts and Kalivas, 1989; Johnson and North, 1992a). Given this arrangement of receptors and synaptic connections, the administration of a $\mathrm{GABA}_{B}$ agonist would hyperpolarize dopamine cells and decrease somatodendritic dopamine release. In contrast, both $\mathrm{GABA}_{\mathrm{A}}$ and $\mu$-opioid agonists would increase somatodendritic dopamine release by inhibiting tonic GABAergic input to the dopamine cell.

\section{References}

Beart PM, McDonald A (1980) Neurochemical studies of the mesolimbic dopaminergic pathway: somatodendritic mechanisms and GABAergic neurones in the rat ventral tegmentum. J Neurochem 34: 1622-1629.

Bourdelais A, Kalivas PW (1991) High sensitivity HPLC assay for GABA in brain dialysis studies. J Neurosci Methods 39:115-121.

Bowcry NG, Hudson AL, Price GW (1987) GABA And $_{A}$ GABA $A_{B}$ rcceptor site distribution in the rat central nervous system. Neuroscience 20:365-383.

Bozarth MA, Wise RA (1981a) Intracranial self-administration of morphine into the ventral tegmental area in rats. Life Sci 29:551555.

Bozarth MA, Wise RA (1981b) Heroin reward is dependent on a dopaminergic substrate. Life Sci 29:1881-1886.

Broekkamp CLE, Phillips AG, Cools AT (1979) Stimulant effects of enkephalin injections into the dopaminergic A10 area. Nature 278: $560-562$.

Cador M, Rivet J-M, Kelley J-M, LeMoal M, Stinus L (1989) Substance $P$, neurotensin and enkephalin injections into the ventral tegmental area: a comparative study on dopamine turnover in several forebrain structures. Brain Res 486:357-363.

Calenco-Choukroun G, Dauge V, Gacel G, Feger J, Roques BP (1991) Opioid $\delta$ agonists and endogenous enkephalins induce different emo- 
tional reactivity than $\mu$ agonists after injection in the rat ventral tegmental area. Psychopharmacology 103:493-502.

Churchill L, Dilts RP, Kalivas PW (1992) Autoradiographic localization of $\gamma$-aminobutyric acid $_{\mathrm{A}}$ receptors with the ventral tegmental area. Neurochem Res 17:101-106.

Dilts RP, Kalivas PW (1989) Autoradiographic localization of muopioid and neurotensin receptors within the mesolimbic dopamine system. Brain Res 488:311-327.

Dilts RP, Kalivas PW (1990) Autoradiographic localization of delta opioid receptors within the mesocorticolimbic dopamine system using radioiodinated [2-penicillamine,5-D-penicillamine]enkephalin ${ }^{125} \mathrm{I}$ DPDPE). Synapse 6:121-132.

Fibiger HC, Phillips AG (1986) Reward, motivation, cognition: psychobiology of mesotelencephalic dopamine systems. In: Handbook of physiology I, vol 4 (Mountcastle VB, Bloom FE, Geiger SR, eds), pp 647-675. Baltimore, MD: Waverly.

Floran B, Silva I, Nava C, Aceves J (1988) Presynaptic modulation of the release of GABA and $\mathrm{GABA}_{\mathrm{A}}$ receptors in pars compacta and by $\mathrm{GABA}_{\mathrm{B}}$ receptors in pars reticulata of the rat substantia nigra. Eur J Pharmacol 150:277-286.

Fonnum F, Gottesfeld Z, Grofova 1 (1978) Distribution of glutamate decarboxylase, choline acetyltransferase and aromatic acid decarboxylase in the basal ganglia of normal and operated rats. Evidence for striatopallidal, striatopeduncular and striatonigral GABAergic fibers. Brain Res 143:125 -138.

Giralt MT, Bonanno G, Raiteri M (1990) GABA terminal autoreceptors in the pars compacta and in the pars reticulata of the rat substantia nigra are $\mathrm{GABA}_{\mathrm{B}}$. Eur J Pharmacol 175:137-144.

Grace AA, Bunney BS (1979) Paradoxical GABA excitation of nigral dopaminergic cells: indirect mediation through reticulata inhibitory neurons. Eur J Pharmacol 59:211-218.

Grace AA, Bumley BS (1980) Effects of baclofen on nigral dopaminergic cell activity following acute and chronic haloperidol treatment. Brain Res Bull 5:537-543.

Grace AA, Bunney BS (1985) Opposing effects of striatonigral feedback pathways on midbrain dopamine cell activity. Brain Res 333:271284.

Gysling K, Wang RY (1983) Morphine-induced activation of A10 dopamine neurons in the rat brain. Brain Res 277:119-127.

Haher SN, Groenewegen HJ, Grove EA, Nauta WJH (1985) Efferent connections of the ventral pallidum: evidence of a dual striatopallidofugal pathway. J Comp Neurol 235:322-325.

Hommer DW, Pert $\Lambda$ (1983) The actions of opioids in the rat substantia nigra: an electrophysiological analysis. Peptides 4:603-608.

Iwamoto ET (1981) Locomotor activity and antinociception after pulative mu, kappa and sigma opioid receptor agonists in the rat: influence of dopaminergic agonists and antagonists. J Pharmacol Exp Ther 217:451-460.

Johnson RB, Sar M, Stumpf WE (1980) A topographic localization of enkephalin on the dopamine neurons in the rat substantia nigra and ventral tegmental area demonstrated by combined histofluorescence immunocytochemistry. Brain Res 194:566-571.

Johnson SW, North RA (1992a) Opioids excite dopamine neurons by hyperpolarization of local interneurons. J Neurosci 12:483-489.

Johnson SW, North RA (1992b) Two types of neurone in the rat ventral tegmental area and their synaptic inputs. J Physiol (Lond) 450:491-502.

Joyce EM, Iversen SD (1979) The effect of morphine applied locally to mesencephalic dopamine cell bodies on spontaneous motor activity in the rat. Neurosci Lett 14:207-212.

Judson BA, Goldstein A (1978) Genetic control of opiate-induced locomotor activity in mice. J Pharmacol Exp Ther 206:56-60.

Kalivas PW, Duffy P (1987) Sensitization to repeated morphine injection in the rat: possible involvement of A10 dopamine neurons. $J$ Pharmacol Exp Ther 241:204-212.

Kalivas PW, Duffy P (1990) Effect of acute and daily neurotensin and enkephalin treatments on extracellular dopamine in the nucleus accumbens. J Neurosci 10:2940-2949.

Kalivas PW, Duffy P (1991) Comparison of somatodendritic and axonal mesolimbic dopamine release using in vivo microdialysis. J Neurochem 56:961-967.

Kalivas PW, Stanley D, Widerlov E, Breese G, Prange AJ Jr (1983) Enkephalin action on the mesolimbic system: a dopamine-dependent and a dopamine-independent increase in locomotor activity. J Pharmacol Exp Ther 227:229-237.

Kalivas PW, Duffy P, Eberhardt H (1990) Modulation of A10 do-

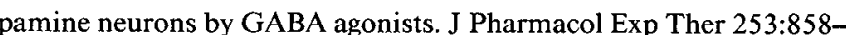
866.

Kelley AE, Stinus L, Iversen SD (1980) Interactions between D-AlaMet-enkephalin, A10 dopaminergic neurons, and spontaneous behavior in the rat. Behav Brain Res 1:3-24.

Khachaturian H, Lewis ME, Watson SJ (1983) Enkephalin systems in diencephalon and brainstem of the rat. J Comp Neurol 220:310320.

Kondo $\mathrm{Y}$, Iwatsubo K (1978) Increased release of preloaded $\left[{ }^{3} \mathrm{H}\right]$ GABA from substantia nigra in vivo following stimulation of caudate nucleus and globus pallidus. Brain Res 154:395-400.

Lacey MG, Mercuri NB, North RA (1988) On the potassium conductance increase activated by $\mathrm{GABA}_{\mathrm{B}}$ and dopamine receptors in rat substantia nigra neurones. J Physiol (Lond) 401:437-454.

Lacey MG, Mercuri NB, North RA (1989) Two cell types in rat substantia nigra zona compacta distinguished by membrane properties and the actions of dopamine and opioids. J Neurosci 9:1233-1241.

Latimer LG, Duffy P, Kalivas PW (1987) Mu opioid receptor involvement in enkephalin activation of dopamine neurons in the ventral tegmental area. J Pharmacol Exp Ther 241:328-337.

MacNeil D, Gower M, Szymanska I (1978) Response of dopamine neurons in substantia nigra to muscimol. Brain Res 154:401-403.

Matthews RT, German DC (1984) Electrophysiological evidence for excitation of rat ventral tegmental area dopamine neurons by morphine. Neuroscience 11:617-625.

Milliken GA, Johnson DE (1984) Analysis of messy data, Vol I, Designed experiments. Belmont, CA: Lifetime Learning.

Moleman P, Bruinvels J (1976) Differential effect of morphine on dopaminergic neurons in frontal cortex and striatum of the rat. Life Sci 19:1277-1282

Nagai T, McGeer PL, McGeer EG (1983) Distribution of GABA-Tintensive neurons in the rat forebrain and midbrain. J Comp Neurol 218:220-238.

Olpe HR, Koella WP, Wolf P, Haas HL (1977) The action of baclofen on neurons of the substantia nigra and ventral tegmental area. Brain Res 134:577-580.

Ottersen OP, Storm-Mathisen J (1984) Neurons containing or accumulating transmitter amino acids. In: Handbook of chemical neuroanatomy (Bjorklund A, Hokfelt T, Kuhar MJ, eds), pp 141-245. Amsterdam: Elsevier.

Pellegrino LK, Pellegrino AS, Cushman AJ (1979) A stereotaxic atlas of the rat brain. New York: Plenum.

Phillips AG, LePaine FG, Fibiger HC (1983) Dopaminergic mediation of reward produced by direct injection of enkephalin into the ventral tegmental area of the rat. Life Sci 33:2505-2511.

Pinnock RD (1984) Hyperpolarizing action of baclofen on neurons in the rat substantia nigra slice. Brain Res 332:337-340.

Ribak CE, Vaughn JE, Roberts E (1980) GABAergic nerve terminals decrease in the substantia nigra following hemitransections of the striatonigral and pallidonigral pathways. Brain Res 192:413-420.

Robertson GS, Damsma G, Fibiger HC (1991) Characterization of dopamine release in the substantia nigra by in vivo microdialysis in the freely moving rat. J Neurosci 11:2209-2216.

Robinson TE, Whishaw IQ (1988) Normalization of extracellular dopamine in striatum following recovery from a partial unilateral 6-OHDA lesion of the substantia nigra: a microdialysis study in freely moving rats. Brain Res 450:209-224.

Santiago M, Westerink BHC (1991) Characterization and pharmacological responsiveness of dopamine release recorded by microdialysis in the substantia nigra of conscious rats. J Neurochem 57:738747.

Seabrook GR, Howson W, Lacey MG (1990) Electrophysiological characterization of potent agonists and antagonists at pre- and postsynaptic $\mathrm{GABA}_{\mathrm{B}}$ receptors on neurons in rat brain slices. Br J Pharmacol 101:949-957.

Sequier JM, Richards JG, Malherbe P, Price GW, Mathews S, Mohler $H$ (1988) Mapping of brain areas containing RNA homologous to cDNAs encoding the $\alpha$ and $\beta$ subunits of the rat GABA $\gamma$-aminobutyrate receptor. Proc Natl Acad Sci USA 85:7815-7819.

Sesack SR, Pickel VM (1990) Synaptic input from opioid terminals to dopaminergic and nondopaminergic neurons in the ventral teymental area of the rat. Eur J Pharmacol 183:208-209.

Sesack SR, Pickel VM (1992) Dual ultrastructural localization of enkephalin and tyrosine hydroxylase immunoreactivity in rat ventral tegmental area: multiple substrates for opiate-dopamine interactions. J Neurosci 12:1335-1350. 
Shippenberg TS (in press) Conditioning of opioid reinforcement: neuroanatomical and neurochemical substrates. Ann NY Acad Sci, in press.

Sugita S, Johnson SW, North RA (1992) Synaptic inputs to GABA and $\mathrm{GABA}_{B}$ receptors originate from discrete afferent neurons. Neurosci Lett 434:207-211.

Tanner $T$ (1979) GABA-induced locomotor activity in the rat after bilateral injection into the ventral tegmental area. Neuropharmacology 18:441-446.

Veith JL, Sandman CA, Walker JM, Coy DH, Kastin AJ (1978) Systemic administration of endorphins selectively alters open field behavior of rats. Physiol Behav 20:539-542.

Vezina P, Kalivas PW, Stewart J (1987) Sensitization occurs to the locomotor effects of morphine and the specific mu opioid receptor agonist, DAGO, administered repeatedly to the VT $\Lambda$ but not to the nucleus accumbens. Brain Res 417:51-58.

Walaas I, Fonnum F (1979) The distribution and origin of glutamate decarboxylase and choline acetyltransferase in ventral pallidum and other basal forebrain regions. Brain Res 177:325-336.

Walters JR, Lakoski JM (1978) Effect of muscimol on single unit activity of substantia nigra dopamine neurons. Eur J Pharmacol 47: $469-471$.
Waszczak BL, Walters JR (1980) Intravenous GABA agonist administration stimulates firing of A 10 dopaminergic neurons. Eur J Pharmacol 66:141-144.

Westerink BHC, Korf J (1976) Regional rat brain levels of 3,4-dihydroxyphenylacetic acid and homovanillic acid: concurrent fluorimetric measurement and influence of drugs. Eur J Pharmacol 38:281291 .

Wirtshafter D, Klitenick MA (1989) Comparative studies of locomotor behavior following microinjections of muscimol into various sites in the paramedian tegmentum. Pharmacol Biochem Behav 32: 625-628.

Wood PI., Stotland M, Richard JW, Rackham A (1980) Actions of $\mathrm{mu}$, kappa, delta and agonist/antagonist opiates on striatal dopaminergic function. J Pharmacol Exp Ther 215:697-703.

Yim CY, Mogenson GJ (1980) Effect of picrotoxin and nipecotic acid on inhibitory response of dopaminergic neurons in the ventral tegmental area to stimulation of the nucleus accumbens. Brain Res 199: $466-472$.

Zhang J-H, Sato M, Tohyama M (1991) Region-specific expression of the mRNAs encoding $\beta$ subunits $\left(\beta_{1}, \beta_{2}\right.$, and $\left.\beta_{3}\right)$ of $\mathrm{GABA}_{\mathrm{A}}$ receptor in the rat brain. J Comp Neurol 303:637-657. 